\title{
KULTURNA DEDIŠČINA IN NJENO VAROVANJE V ČASU OBOROŽENIH SPOPADOV
}

Povzetek Kulturna dediščina oziroma kulturne dobrine so izraz zgodovinske tradicije nekega naroda. V zgodovini vojskovanja je bila kulturna dediščina pogosto uničena, poškodovana in izropana. Prispevek predstavlja zgodovinski razvoj mednarodnopravne zaščite kulturnih dobrin, obveznosti, ki jih imajo visoke pogodbenice Konvencije o varstvu kulturnih dobrin v primeru oboroženega spopada, nekatera najpomembnejša pravila glede varovanja kulturnih dobrin med oboroženimi spopadi, slovensko delovanje na obravnavanem področju ter pozitivne in negativne posledice (ne)varovanja kulturnih dobrin.

Ključne Varovanje kulturnih dobrin, oboroženi spopadi, Haaška konvencija.

besede

Abstract Cultural heritage and cultural property are an expression of the historical tradition of a certain nation. Throughout the history of warfare, cultural heritage has often been destroyed, damaged and looted. The article presents the historical development of international legal protection of cultural property, the obligations of the High Contracting Parties to the Convention for the Protection of Cultural Property in the Event of Armed Conflict, some of the most important rules regarding the protection of cultural property in armed conflicts, Slovenian activities in this field, and the positive and negative consequences of the (non-) protection of cultural property.

Protection of cultural property, armed conflicts, Hague Convention. 
Uvod Kulturna dediščina so dobrine, podedovane iz preteklosti, ki jih posamezniki opredeljujejo kot odsev in izraz svojih vrednot, identitet, verskih in drugih prepričanj, znanja in tradicije. Vključuje vidike okolja, ki izhajajo iz medsebojnega vplivanja med ljudmi in prostorom skozi čas. ${ }^{1}$

Izkušnje kažejo, da kultura in kulturna dediščina igrata pomembno vlogo v modernih oboroženih spopadih. Praktično v živo smo lahko spremljali uničenje Starega mostu čez reko Neretvo v Mostarju, bombardiranje starega dubrovniškega mestnega jedra, uničenje antične Palmire ali znamenitih kipov bud iz Bamijana. Uničenje dediščine lahko pretrga povezave s preteklostjo in izbriše identiteto posameznega naroda iz zgodovinskega spomina.

Kar danes poimenujemo kot kulturna dobrina ${ }^{2}$, je imelo pomembno vlogo med oboroženimi spopadi od najstarejših časov dalje. Plenjenje je bil pogosto najpomembnejši cilj vojne. Že v Pravilih vojne, ki jih najdemo v 5. Mojzesovi knjigi, je zapisano: »Le ženske, otroke, živino in vse, kar je v mestu, ves plen v njem zapleni zase in uživaj plen svojih sovražnikov, ki ti ga da GOSPOD, tvoj Bog! (Sveto pismo, 2016, str. 210). Način vojskovanja, ki je bil povezan s plenjenjem in ropanjem, pa tudi uničevanjem vsega, kar je pripadalo nasprotniku, se je do konca uveljavil med rimskimi osvajanji vsega takrat znanega sveta (Jogan, 2008, str. 15). V času prve judovsko-rimske vojne, ki je potekala med letoma 66 in 73, so rimske vojaške enote pod poveljstvom poznejšega cesarja Tita Flavija uničile velik del Jeruzalema in tempelj. Po Titovi smrti je bil v spomin nanj v Rimu zgrajen Titov slavolok, na katerem so upodobljeni vojaki, ki odnašajo plen izjeruzalemskega templja. Postavitev rimskega Koloseja je bila financirana s plenom, pridobljenim v tej vojni (Turku, 2018, str. 33). Med Napoleonovimi osvajanji je potekalo sistematično plenjenje umetniških del premaganih držav. Tudi v novejšem času so bili naši predniki priče uničenju kulturne dediščine. Med drugo svetovno vojno uničeni samostan Monte Cassino predstavlja simbol uničenja kulturnih dobrin med oboroženim spopadom.

\footnotetext{
Povzeto po definiciji dediščine iz drugega odstavka prvega člena Zakona o varstvu kulturne dediščine (ZKVD1), ki je bil sprejet 1. 2. 2008. Konvencija o varstvu kulturnih dobrin v primeru oboroženega spopada uporablja termin kulturne dobrine. Konvencija šteje za kulturne dobrine:

a) premičnine ali nepremičnine, ki so pomembne za kulturno dediščino vsakega naroda, kot so arhitekturni, umetnostni ali zgodovinski spomeniki, verski ali posvetni spomeniki, arheološka območja, skupine zgradb, ki so kot celote zgodovinsko ali umetnostno zanimive, umetnine, rokopisi, knjige in drugi umetnostno, zgodovinsko ali arheološko zanimivi predmeti ter znanstvene zbirke in pomembne zbirke knjig, arhivov ali reprodukcije prej naštetih del;

b) stavbe, katerih poglavitni in stvarni namen je, da varujejo ali razstavljajo premične kulturne dobrine, opredeljene v odstavku a), kot so muzeji, velike knjižnice, arhivska skladišča in tudi zaklonišča, namenjena zavarovanju v odstavku a) opredeljenih premičnih kulturnih dobrin ob oboroženem spopadu;

c) središča, v katerih je znatno število kulturnih dobrin, ki so navedena vodstavkih a) in b), tako imenovana spomeniška središča.

2 Konvencija o varstvu kulturnih dobrin v primeru oboroženega spopada uporablja termin »kulturne dobrine«, zato je ta termin uporabljen tudi v prispevku.
} 


\section{RAZVOJ MEDNARODNOPRAVNEGA VARSTVA KULTURNIH DOBRIN}

Stoletja dolgo je veljalo, da so dovoljena vsa sredstva za dosego cilja, dokler je cilj vojne pravičen. Vsa lastnina nasprotnika je lahko bila uničena, če je to pripomoglo $\mathrm{k}$ vojaški zmagi. Kot neke vrste začetek sistema varstva kulturnih dobrin lahko štejemo določilo delfske zveze starogrških držav iz leta 1100 pred našim štetjem, ki prepoveduje rušenje mest do njihovih temeljev (Kladnik, 2010, str. 180). V času rimskega imperija so posamezniki opozarjali na nesmiselno uničevanje kulturnih dobrin. Rimski državnik, pravnik, politični teoretik in filozof Cicero je svetoval, da se cilji vojne prilagodijo zakonu tako, da se upošteva zmernost pri plenitvi (Jogan, 2008, str. 15). V 16. stoletju so se začele pojavljati zamisli, da spomeniki in umetniška dela predstavljajo posebno kategorijo lastnine, ki jo je med vojno treba zaščititi. Nekateri teoretiki mednarodnega prava so menili, da uničevanje kulturnih objektov skoraj nikoli ni upravičevalo vojaškega cilja. Verjetno najbolj konkreten v tem razmišljanju je bil Emer de Vattel, ki je v svojem delu Le Droit des Gens, ou Principes de la Loi Naturelle zapisal, da ne glede na razloge, zaradi katerih napadalec opustoši državo, mora prizanesti zgradbam, ki slavijo človeka in ki ne pripomorejo k sovražnikovi moči, kot so templji, grobnice, javne zgradbe in druga umetniška dela. Le zagrizen sovražnik človeštva lahko ljudi prikrajša za takšne spomenike (O`Keefe, 2006, str. 11). Nihče izmed razsvetljenskih mislecev pa še ni razvil posebne misli, namenjene zaplembi nasprotnikovega premoženja, do katerega je imel po veljavnem mednarodnem pravu zmagovalec vso pravico.

Francoska revolucija in napoleonske vojne, ki so ji sledile, predstavljajo prelomnico $\mathrm{v}$ pravni zaščiti spomenikov in umetniških predmetov. Močne strasti, ki jih je razvnela francoska revolucija, so predstavljale veliko nevarnost za umetniška dela na francoskih tleh. Leta 1790 je bila ustanovljena posebna komisija, ki je prevzela skrb nad zaplenjeno kulturno dediščino plemstva, Cerkve in francoskih emigrantov, dediščino, kije bila od takrat naprej last vseh (O`Keefe, 2006, str. 13-14). Tudi nekoliko pozneje izdani dekreti, ki so opredeljevali uničenje ostankov predrevolucionarnega despotizma, so kot izjeme predvidevali umetniška dela velike vrednosti. Zunaj Francije pa je Napoleonova osvajanja spremljalo sistematično plenjenje umetniških del premaganih držav. Francoska država je deloma s silo deloma pa z izsiljenimi pogodbami napolnila Museé Central des Arts (Senković, 2013, str. 4). Inspiracija za ta dejanja je bila vizija panevropske kulture, katere najprimernejši skrbnik bi bila Francija, republika med tiranijami. Po Napoleonovem padcu je bila Franciji ukazana vrnitev zaplenjenih del.

Medtem pa je na drugem koncu Atlantika novo načelo, da so umetniška dela del skupne dediščine človeštva in da kot taka uživajo poseben status, dobilo potrditev v sodbi britanskega pomorskega sodišča v Novi Škotski. Sodišče je ukazalo vrnitev umetniških del, ki jih je angleška mornarica zaplenila med anglo-ameriško vojno leta 1812 (O`Keefe, 2006, str. 15). 


\subsection{Lieberjev kodeks}

Prva kodifikacija vojnega prava, Generalni ukaz št. 100 oz. Lieberjev kodeks, ki ga je predsednik Lincoln izdal med ameriško državljansko vojno, vsebuje tudi prva pravila, namenjena varovanju kulturnih dobrin. V 35. členu kodeksa je zapisano, da morajo biti klasična umetniška dela, knjižnice, znanstvene zbirke ali dragoceni inštrumenti in tudi bolnišnice, zaščiteni tudi takrat, če so v utrjenih mestih med obleganjem ali bombardiranjem (Instructions for the Government of Armies of the United states in the Field, člen 35, 1863). Lieberjev kodeks je vplival na Bruseljsko deklaracijo iz leta 1874 in na Oxfordski priročnik iz leta 1880, ki sta prepovedovala uničenje nasprotnikove lastnine, če to ni zahtevala vojaška nujnost.

\subsection{Druga (1899) in Četrta (1907) Haaška konvencija}

Prvi mednarodni pogodbi, ki sta bili namenjeni tudi zaščiti kulturnih dobrin med oboroženim spopadom, sta bili Druga in Četrta Haaška konvencija o zakonih in običajih vojne na kopnem ter pripadajoča pravilnika iz 1899 in 1907 (Keane, 2004, str. 4).

Sedemindvajseti člen pravilnika iz leta 1907 določa, da je med obleganji in bombardiranjem treba storiti vse, da se zaščitijo objekti, namenjeni veri, umetnosti, znanosti ali dobrodelnim dejavnostim, zgodovinski spomeniki, bolnišnice in kraji, kjer so zbrani bolni in ranjeni, če ti objekti niso uporabljeni v vojaške namene. Isti člen napadenemu nalaga dolžnost, da z očitnimi in jasno vidnimi znaki označi zaščitene zgradbe ter o tem obvesti nasprotnika (Haaški pravilnik o zakonih in običajih vojne na kopnem, člen 27, 1907). Pravilnik ne govori o tem, kako naj bi bil videti tak znak, je pa opisan v Haaški konvenciji o bombardiranju pomorskih sil med vojno iz $1907 .{ }^{3}$ Treba je omeniti tudi točko g 23. člena pravilnika, ki dovoljuje uničenje sovražnikove lastnine, torej tudi kulturne dobrine, v primeru vojaške nujnosti (Haaški pravilnik o zakonih in običajih vojne na kopnem, člen 23 g, 1907). Haaški pravilnik tako očitno prepoveduje samo bombardiranje zgoraj naštetih objektov in zgodovinskih spomenikov, vse druge oblike napada na takšne objekte pa dovoljuje. Pravilnik govori tudi o zaščiti kulturne dediščine med okupacijo. V njegovem 56. členu je zapisano, da je lastnina institucij, namenjenih veri, dobrodelnosti, izobraževanju, umetnosti in znanosti, zasebna lastnina, tudi ko gre za last države. Vsako plenjenje, uničenje ali namerno poškodovanje lastnine teh institucij, zgodovinskih spomenikov in umetniških del je prepovedano in bo predmet pravdnih postopkov (Haaški pravilnik o zakonih in običajih vojne na kopnem, člen 56, 1907).

Določila Haaškega pravilnika o zakonih in običajih vojne na kopnem so postala pravila običajnega prava in kot taka še veljajo. Pravilnik je vzpostavil tri načela glede zaščite kulturne dediščine. Kulturni spomeniki in objekti, namenjeni znanosti in umetnosti, ki morajo biti označeni z vidnimi znaki, so zaščiteni pred vojaškim

5. člen Haaške konvencije o bombardiranju pomorskih sil med vojno določa znak pravokotne oblike, ki je diagonalno razdeljen na dva trikotna dela; zgornji trikotnik je črne, spodnji pa bele barve. 
napadom, razen ko so uporabljeni za vojaški namen. Taka zaščita je podrejena vojaški nujnosti. Ob okupaciji mora biti kulturna dediščina obravnavana kot zasebna lastina; okupant je ne sme poškodovati, uničiti ali zapleniti (Senković, 2013, str. 7).

\subsection{Svetovni vojni}

Prva svetovna vojna je izpostavila neustreznost dotedanjega pravila o bombardiranju, ki je prepovedoval vsakršen napad ali bombardiranje nebranjenih krajev in vasi. Zaradi tehnološkega napredka različnih tipov orožja je bilo lahko praktično vsako mesto $\mathrm{v}$ zaledju fronte izpostavljeno zadetkom nasprotnikovega topništva ali letalstva. In zaradi visoke stopnje vojaške mobilizacije so bile vojaške enote nastanjene tudi v krajih v zaledju fronte in v nekem širšem smislu so bili ti kraji tudi branjeni. Posledično je bila vsa zasebna lastnina, razen kulturnih dobrin, ki jih je varoval 27. člen Haaškega pravilnika o zakonih in običajih vojne na kopnem, izpostavljena legalnemu napadu.

Prva svetovna vojna je torej pokazala, da so bila pravila o bombardiranju preohlapna. Komisija pravnikov, ki jo je leta 1922 imenovala Washingtonska konferenca o zmanjševanju oboroževanja, je pripravila osnutek pravil o zračnem bojevanju, ki je bil sprejet leto pozneje (Senković, 2013, str. 8). V osnutku je razlikovanje med branjenimi in nebranjenimi kraji nadomestilo razlikovanje med vojaškimi objekti in civilnim prebivalstvom. Prvi člen govori o tem, da je zračno bombardiranje legitimno le, ko je usmerjeno na vojaški cilj. Osnutek je zavezal vojaške poveljnike, da morajo storiti vse, kar je v njihovi moči, da se prizanese objektom, omenjenim v Haaškem pravilniku o zakonih in običajih vojne na kopnem (O`Keefe, 2006, str. 45). Osnutek ni bil nikoli formalno potrjen, saj ga je prehitela druga svetovna vojna, je pa predstavljal osnovo za nadaljnjo zaščito kulturnih dobrin. Napredek na tem področju je predstavljal tudi Roerichov pakt, ki predvideva nevtralnost zgodovinskih objektov. Ta je lahko kršena le takrat, ko se ti objekti uporabljajo za vojaške namene. Pakt uvaja tudi razpoznavni znak - rdeča krožnica na beli podlagi s tremi rdečimi krogi znotraj krožnice - za označevanje zaščitenih objektov. Roerichov pakt je podpisalo deset ameriških držav, ki so ga pozneje tudi ratificirale. Sporazum, ki se med državami pogodbenicami še vedno uporablja, je močno vplival na nastanek Haaške konvencije.

Druga svetovna vojna se je začela ob zelo neugodnem času za nadaljnji razvoj zaščite kulturnih dobrin. Vojaška nujnost, ki je še vedno imela prednost pred zaščito kulturnih dobrin, je vplivala na uničenje številnih mestnih središč in posameznih zgodovinskih spomenikov velike vrednosti za celotno človeštvo. Najbolj znan primer, morda celo simbol uničenja kulturnih dobrin med drugo svetovno vojno, je bombardiranje benediktinskega samostana Monte Cassino v Italiji. Nemška obrambna črta je potekala v bližini samostana, a nemške sile samostana niso zasedle. Zaradi napačnih obveščevalnih podatkov, da samostan uporablja nemška vojska, je zavezniški general Freyber ukazal bombardiranje samostana. Ruševine samostana so nato zasedle nemške enote in jih spremenile v utrdbo, ki je zavezniškim vojakom ni uspelo zavzeti vse do umika nemških enot. Da se uničevanje kulturnih dobrin ne 
bi ponovilo še na drugih območjih, so zavezniki pred invazijo v Normandiji zaostrili pravila bojevanja. General Eisenhower je poudaril, da gre v bitki za Evropo tudi za bitko za ohranitev civilizacije. »Na tej poti bodo naleteli na zgodovinske spomenike in kulturna središča, ki za svet simbolizirajo vse tisto, kar je treba ohraniti. Vsak poveljnik mora spoštovati in zavarovati te simbole ...«(Jogan, 2008, str. 46).

Kulturnim dobrinam pa ni grozila le nevarnost uničenja med vojaškimi spopadi. Nemške vojaške enote so z območij, kjer so izvajale okupacijo, prepeljale v Nemčijo številna umetniška dela. Mednarodno sodišče za vojne zločine v Nürnbergu je Alfreda Rosenberga, vodjo posebne enote Einsatzstab Rosenberg, katere naloga je bila obogatitev nemških umetniških zbirk, obsodila na smrt za vojne zločine in zločine proti človeštvu. Smrtna kazen je bila izvedena 16. oktobra 1946 (Keane, 2004, str. 12). Proces proti Rosenbergu in nekaterim drugim nacističnim veljakom, ki so bili obsojeni za plenjenje kulturnih dobrin, velja za prvo resno mednarodno uveljavljanje pravne zaščite kulturnih dobrin (Gottlieb, 2020, str. 293).

\subsection{Haaška konvencija}

Leta 1949 je Organizacija Združenih narodov za izobraževanje, znanost in kulturo ${ }^{4}$ začela priprave na nov dogovor o zaščiti kulturnih dobrin med oboroženimi spopadi. Leto pozneje je generalni direktor sklical delovno skupino, ki je pripravila osnutek pogodbe. Med 21. aprilom in 14. majem 1954 je v nizozemskem Haagu potekala medvladna konferenca, na kateri so sodelovale delegacije iz 56 držav. 14. maja 1954 sta bila sprejeta Konvencija o varstvu kulturnih dobrin v primeru oboroženega spopada $^{5}$ in Pravilnik za izvrševanje Konvencije, ki je integralni del Haaške konvencije, ter Protokol k Haaški konvenciji, danes poznan kot Prvi protokol. Oba dokumenta sta začela veljati 7. avgusta 1956 (O`Keefe, 2006, str. 93-94). ${ }^{6} \mathrm{~V}$ preambuli Haaške konvencije je zapisano: »/. . ./ kulturnim dobrinam prizadeta škoda ne glede na to, kateremu narodu pripadajo, pomeni oškodovanje kulturne dediščine vsega človeštva, saj prispeva vsak narod k svetovni kulturi svoj delež. « (Konvencija o varstvu kulturnih dobrin v primeru oboroženega spopada, 1954, str. 1). Haaška konvencija je prvi mednarodni sporazum, ki govori izključno o zaščiti kulturnih dobrin med oboroženim spopadom. Najpomembnejši člen Haaške konvencije je njen 4. člen. Z njim so se države pogodbenice zavezale, da bodo v času oboroženega spopada spoštovale kulturne dobrine, ki so na njihovem ozemlju in tiste na ozemlju drugih držav pogodbenic (Konvencija o varstvu kulturnih dobrin v primeru oboroženega spopada, 1954, str. 2). 16. člen Haaške konvencije opredeljuje znak konvencije. Ta ima obliko ščita, ki je spodaj priostren, razdeljen na štiri navzkrižna polja, obarvan modro in belo; ( ̌̌čit je sestavljen iz modrega kvadrata, katerega eden od oglov predstavlja spodnji del ščita, in iz modrega trikotnika nad kvadratom, tako

\footnotetext{
4 Vnadaljevanju Unesco.

Vnadaljevanju Haaška konvencija.

${ }^{6}$ Držav pogodbenic Haaške konvencije je trenutno 133, držav pogodbenic Prvega protokola je 110.
} 
da oba skupaj z obeh strani omejujeta po en bel trikotnik (Konvencija o varstvu kulturnih dobrin v primeru oboroženega spopada, 1954, str. 6 ). ${ }^{7}$

Haaška konvencija ni izpolnila pričakovanj, ki so se pojavila ob njenem nastanku. Razlogov za toje več. Zaščita, ki joje zagotavljala kulturnim dobrinam, je predstavljala le majhen napredek glede na do njenega nastanka veljavne omejitve bojevanja. Režim posebnega varstva, ki ga je predvidela, se je izkazal za neuporabnega, prav tako sistem mednarodnega nadzora, ki je bil preambiciozen in zato neuresničljiv. S sprejetjem dodatnih protokolov k Ženevskim konvencijam iz leta 1977 pa je Haaška konvencija postala zastarela (Senković, 2013, str. 11-12).

\subsection{Drugi protokol}

Haaška konvencija je ponovno postala aktualna v 80. in 90. letih 20. stoletja. V iranskoiraški vojni je prišlo do uničenja kulturnih dobrin na obeh, v vojno vpletenih straneh. Prav tako se je zgodilo med vojaškimi spopadi na ozemlju nekdanje Jugoslavije. Leta 1991 je nizozemska vlada naročila recenzijo Haaške konvencije. Poročilo je pokazalo, da je Haaška konvencija še vedno veljavna in delujoča pogodba, katere težava je neupoštevanje izvedbe. Revizija konvencije je svoj vrhunec dosegla na konferenci v Haagu leta 1999, na kateri so delegati 26. marca sprejeli Drugi protokol k Haaški konvenciji o varstvu kulturnih dobrin v primeru oboroženega spopada (Senković, 2013, str. 12).

Drugi protokol Haaško konvencijo dopolnjuje in jo v nobenem primeru ne nadomešča. Pomembnejše spremembe, ki jih prinaša Drugi protokol, so členitev odgovornosti za varstvo kulturnih dobrin, seznam ukrepov, ki naj jih članice sprejmejo v miru, in vzpostavitev sklada za pomoč pri izvedbi teh ukrepov, definicija vojaške nujnosti, zahteva po sorazmernosti napadov, prepoved arheoloških izkopavanj na okupiranih območjih, vzpostavitev razširjenega varstva ter definicija kazenskih sankcij zaradi kršitve konvencije. V 15. členu je opredeljenih pet kršitev, za katere se uvaja individualna kazenska odgovornost (Drugi protokol k Haaški konvenciji o varstvu kulturnih dobrin v primeru oboroženega spopada, člen 15, 1999).

\subsection{Dopolnilna protokola I in II k Ženevskim konvencijam iz leta 1949}

Dopolnilna protokola I in II k Ženevskim konvencijam iz leta 1949 sta bila sprejeta leta 1977. Prvi Dopolnilni protokol pokriva področje mednarodnih oboroženih spopadov, drugi pa področje notranjih oboroženih spopadov. Oba vsebujeta tudi člene, ki se nanašajo na kulturne dobrine.

Tako kot Haaška konvencija tudi Dopolnilna protokola I in II k Ženevskim konvencijam iz leta 1949 govorita o zaščiti kulturnih dobrin, le da sta v opredelitvah zaščite nekoliko »ožja«. 53. člen Dopolnilnega protokola I prepoveduje storiti

\footnotetext{
Nekateri dogodki potrjujejo, da označitev kulturne dobrine pripomore k njenemu uničenju. Nedolgo zatem, ko so med obleganjem Vukovarja leta 1991 na Vukovarski muzej namestili znak konvencije, je ta postal cilj obstreljevanja pripadnikov JLA.
} 
kakršno koli sovražno dejanje proti zgodovinskim spomenikom, umetniškim delom ali svetiščem, ki so kulturna in duhovna dediščina naroda. 16. člen Dopolnilnega protokola II pa dodatno prepoveduje uporabo omenjenih kulturnih dobrin za podporo vojaškemu delovanju (Zidar, 2019, str. 342). V teh primerih gre za zaščito kulturnih dobrin naroda, medtem ko Haaška konvencija govori o celotnem človeštvu. Kljub razlikam v definicijah lahko iz komentarja Mednarodnega ICRC k Dopolnilnim protokolom I in II razberemo, da je osnovna ideja vseh dokumentov enaka (Rawan, 2017, str. 105; O‘Keefe, 2006, str. 209).

\section{SPOŠTOVANJE KULTURNIH DOBRIN}

Skrb za kulturne dobrine zadnja leta ni več v izključni domeni kulturnega sektorja, temveč se je preselila oziroma se seli tudi na obrambni sektor. Kulturne dobrine so vse bolj vpete v oborožene spopade zaradi njihovega izjemnega pomena, ki ga imajo v posameznih družbah, ter zaradi političnega vpliva, ki ga ima njihovo uničenje. V preambuli Severnoatlantske pogodbe piše, da so pogodbenice odločene varovati svobodo, skupno dediščino in civilizacijo svojih narodov, ... (Severnoatlantska pogodba, preambula, 1949). Varovanje kulturnih dobrin kot del varovanja skupne dediščine tako predstavlja tudi vrednoto organizacije Nato.

Varovanje kulturnih dobrin med oboroženimi spopadi ima za vojaške sile strateški in pravni pomen ter verjetno nima takojšnjega neposrednega učinka na vojaško operacijo, nasprotno pa lahko uničenje ali poškodovanje, kraje in drugo neustrezno ravnanje s kulturnimi dobrinami ogrozi uspeh operacije ter lahko negativno odmeva v lokalni in svetovni javnosti. Lokalno prebivalstvo se lahko zaradi nespoštovanja kulturnih dobrin obrne proti pripadnikom oboroženih sil, ki delujejo na določenem območju. Ropanje Iraškega nacionalnega muzeja leta 2003 je na primer preraslo v simbol popolne nemoči okupacijskih sil preprečiti vsesplošni kaos. Ko imajo oborožene sile možnost preprečiti ropanje kulturnih dobrin, pa tega ne storijo, ima to lahko dolgotrajen vpliv na ugled vojaške operacije. Nezakonito trgovanje s kulturnimi dobrinami predstavlja finančni prihodek za različne oborožene skupine in teroristične organizacije, torej bi varovanje kulturnih dobrin odrezalo te skupine od znatnega dela njihovih virov financiranja. Skrb za kulturne dobrine pozitivno vpliva na odnose z javnostjo, saj tako lahko na svojo stran pridobijo prebivalce določene regije ali države (Foilant, 2015, str. 15), pridobita se njihova »razum in srce ${ }^{8}{ }^{8}$ Razumevanje pomena kulturnih dobrin, povezano $\mathrm{z}$ njihovo spoštljivo obravnavo, lahko deluje kot multiplikator bojne moči (Senković, 2013, str. 52). To se je posebej pokazalo v operaciji Unified Protector. Obveščevalni strokovnjaki so ob pomoči libijskih arheologov in zgodovinarjev ter različnih vladnih, nevladnih in mednarodnih organizacij sestavili nabor libijskih kulturnih dobrin, ki so zahtevale posebno pozornost. Ta nabor so nato vključili v t. i. »no-strike list«, ki so ga Natove sile upoštevale pri izvajanju vojaških akcij (O`Keefe in drugi, 2016, str. 30). Pozitivna publiciteta, ki jo je Nato prejel na podlagi preprečevanja uničenja kulturnih dobrin

8 Angl. hearts and minds. 
v Libiji, je še danes v strokovnih krogih uporabljena za zgled delovanja na tem področju.

V pravnem smislu je neuspeh neke vojaške sile, da bi upoštevala vse ukrepe za zaščito kulturnih dobrin, ki jih predvideva mednarodno pravo, neuspeh države, iz katere prihaja ta vojaška sila. Taki državi bi bilo lahko naloženo plačilo odškodnine za uničenje kulturnih dobrin (O'Keefe in drugi, 2016, str. 2). ${ }^{9}$ Vsaka posameznica in posameznik, ki nosita uniformo, sta odgovorna za uničenje ali poškodovanje kulturnih dobrin med oboroženim spopadom in se lahko zaradi tega znajdeta pred sodiščem z obtožbo za vojne zločine ter celo za zločine proti človeštvu. ${ }^{10}$ Pri tem je treba omeniti, da se med odgovorne ne štejejo le posamezniki, ki so kulturno dobrino ali dobrine v resnici uničili ali poškodovali, temveč tudi poveljniški kader, ki ne prepreči takih zločinov.

Treba je tudi omeniti, da povečan interes mednarodne skupnosti glede varovanja kulturnih dobrin med oboroženimi spopadi pomeni svojevrsten paradoks. Bolj kot strokovna in splošna javnost govorita o pomenu kulturnih dobrin in njihovega varovanja, bolj te kulturne dobrine postajajo taktično in strateško zanimiv cilj oboroženih skupin in terorističnih organizacij. Nekatere raziskave nakazujejo, da se je pozornost Islamske države Iraka in Levanta usmerila na antično Palmiro in njeno uničenje šele po tem, ko sta mednarodna skupnost in zlasti Unesco izrazila skrb za njeno usodo (Rosén, 2017a, str. 17).

\section{IMPLEMENTACIJA HAAŠKE KONVENCIJE}

Haaška konvencija zavezuje države pogodbenice k zaščiti lastnih kulturnih dobrin. O tem govori 3. člen Haaške konvencije: »Visoke pogodbenice se zavezujejo, da bodo že v mirnem času pripravile zavarovanje kulturnih dobrin, ki so na njihovem ozemlju, pred verjetnimi posledicami oboroženega spopada, tako da bodo sprejele vse ukrepe, ki jih imajo za nujno potrebne« (Konvencija o varstvu kulturnih dobrin v primeru oboroženega spopada, 1954, str. 2).

Najpomembnejši ukrepi, ki jih mora država pogodbenica Haaške konvencije izvajati zlasti v obdobju miru, so:

- priprava zaščite: sestava inventarjev, načrtovanje varnostnih ukrepov proti požaru in porušitvi, priprava premične dediščine za evakuacijo oziroma zagotovitev možnosti zavarovanja in situ ter opredelitev odgovornosti, ki je uporabna tudi ob drugih oblikah ogroženosti dediščine;

\footnotetext{
Združeni narodi so naložili Iraku plačilo odškodnine v znesku 19 milijonov ameriških dolarjev nekemu kuvajtskemu zbiratelju kot nadomestilo za uničenje in krajo delov zbirke, ki so ju povzročili pripadniki iraške vojske med invazijo na Kuvajt.

${ }^{10}$ Mednarodno kazensko sodišče je leta 2016 obsodilo Ahmada al Faqija Al Mahdija na devet let zapora zaradi napada na verske in zgodovinske objekte v Timbuktuju. Tako je postal prva oseba, obsojena le zaradi zločina nad kulturnimi dobrinami.
} 
- določitev omejenega števila kulturnih dobrin, ki jih je mogoče postaviti pod posebno zaščito oziroma $\mathrm{v}$ mednarodni register kulturne dediščine;

- načrtovanje posebej izurjenega osebja oziroma posebnih služb, ki bodo znotraj oboroženih sil zagotavljale spoštovanje do kulturne dediščine in sodelovanje s civilnimi oblastmi;

- popularizacija besedil Haaške konvencije in njenega Drugega protokola;

- odstranitev premičnih kulturnih dobrin iz bližine vojaških objektov in morebitnih ciljev ter preprečitev postavljanja vojaških objektov $\mathrm{v}$ bližini kulturnih dobrin (Kladnik, 2010, str. 178).

Finska predstavlja dober zgled glede implementacije Haaške konvencije. V sklopu mirnodobnih priprav so na ravni države začeli pripravljati seznam kulturnih dobrin, tako premičnih kot nepremičnih. Ta seznam bo uporabljen za zaščito izbranih kulturnih dobrin pred naravnimi in drugimi nesrečami ter ob vojaški grožnji. Seznam temelji na merilih, ki so v Haaški konvenciji, ki pa so zelo relativni. Tako so se finski strokovnjaki znašli pred znano dilemo, kje je meja, ki loči pomembnejše in manj pomembne kulturne dobrine. Odločili so se, da bodo odločali o vsaki kulturni dobrini posebej. Naslednji korak v projektu pa predstavlja ocena ogroženosti vsake kulturne dobrine, ki je svoje mesto dobila na seznamu (Pesu, 2012, str. 91-95).

Ravnanje Hrvaške leta 1991 je prav tako primer zglednega ukrepanja ob grožnji oboroženega spopada. Pred začetkom oboroženih spopadov so ustrezne ustanove izvedle izobraževanja za muzejske delavce o ravnanju s kulturnimi dobrinami $\mathrm{v}$ izrednih razmerah. Ti so na mikrofilmih sistematično zabeležili stanje muzejskih zbirk, mikrofilmi pa so bili shranjeni na treh različnih lokacijah. Stalne zbirke so preselili iz muzejev in galerij na varnejša mesta. Stavbe so bile izbrane vnaprej, pregledali pa so jih tudi ustrezni strokovnjaki. Tako so zavarovali več kot 6000 zabojev umetnin. Nepremični spomeniki so bili zavarovani z različnimi tehničnimi ukrepi. Iz cerkev so evakuirali dragocene predmete; težje predmete, kot so oltarji in orgle, pa so bili zavarovani in situ. Po topniškem napadu na zgodovinsko utrdbo v Erdutu leta 1991 so hrvaške oblasti na jugoslovanski Zvezni sekretariat za obrambo poslale sezname zavarovanih kulturnih dobrin (Senković, 2013, str. 19-20).

\section{STANJE V SLOVENIJI}

Republika Slovenija še nima pripravljenega inventarja najpomembnejših kulturnih dobrin, kot ga predvideva Haaška konvencija (Kladnik, 2013, str. 189). Deloma bi ga lahko nadomestil Register kulturne dediščine, ki je osrednja zbirka podatkov o dediščini v Sloveniji. Register nepremične kulturne dediščine Ministrstvo za kulturo razvija od leta 1991. Leta 2009 se mu je pridružil Register nesnovne kulturne dediščine, register premične kulturne dediščine pa še ni vzpostavljen (Register kulturne dediščine).

Sistematično urejanje področja varovanja kulturnih dobrin med oboroženimi spopadi se je začelo v prvem desetletju 21. stoletja. V okviru Ciljnih raziskovalnih programov 
Znanje za varnost in mir 2006-2010 sta potekala dva projekta, ki ju je financiralo Ministrstvo za obrambo Republike Slovenije, strokovni nadzor nad projektoma pa je opravljal Vojaški muzej SV.

Projekt M4-0207, poimenovan Izdelava in demonstracija modela za načrtovanje ohranjanja umetnostnozgodovinske dediščine v vojnih spopadih, je bil zasnovan kot raziskava, ki bo prispevala $\mathrm{k}$ ohranjanju slovenske umetnostnozgodovinske dediščine. $\mathrm{Z}$ raziskavo je bil oblikovan model za načrtovanje ohranjanja umetnostnozgodovinskih spomenikov v primeru vojne, terorizma in naravnih nesreč. Zasnovan je bil kot interdisciplinarna raziskava, v kateri so sodelovali strokovnjaki umetnostnozgodovinske in gradbene stroke (Murovec, 2009, str. 4). Projekt je zajel 70 vrhunskih spomenikov slovenske sakralne umetnosti, ki so bili izbrani po različnih umetnostnozgodovinskih in zunanjih merilih, kot so kakovost, slog, regionalna pokritost, stanje ohranjenosti spomenika, nacionalni pomen, strateška lega objekta itn. V sklopu projekta so bili zbrani vsi pravni akti s področja varovanja kulturne dediščine, pripravljen je bil arhiv spomenikov z izčrpno fotografsko dokumentacijo, arhitektonskimi posnetki in analizami materialov ter tehnik in s predlogi fizičnih ter drugih zaščitnih ukrepov. Pripravljena je bila natančna dokumentacija o vseh 70 izbranih spomenikih ter narejen zemljevid umetnostnih spomenikov državnega pomena. Hkrati je bila narejena tudi metodologija za oceno ogroženosti spomenikov (Murovec, 2009, str. 4, 8).

Projekt M4-0228, poimenovan Varovanje kulturne dediščine v izrednih razmerah, je bil pripravljen zaradi analize takratnega dokumentiranja in praktične ter pravne zaščite predmetov in objektov kulturne dediščine v izrednih razmerah. Temeljni cilj projekta je bila priprava smernic za dokumentiranje in spremljanje stanja spomenikov premične in nepremične kulturne dediščine. V okviru projekta je bila izdana tudi znanstvena monografija Pravno varstvo dediščine avtorja Savina Jogana (Guštin, 2009, str. 4, 7).

S tema projektoma je Republika Slovenija začela izpolnjevati svoje obveznosti kot podpisnica Haaške konvencije in pripravila ustrezen sistem varovanja kulturne dediščine državnega pomena ob oboroženem spopadu. A dobro delo bi bilo treba nadaljevati in projekt razširiti tudi na preostale vrhunske primerke nepremične kulturne dediščine, arheološke ostaline in objekte, ki hranijo premično kulturno dediščino.

\section{UKREPI VOJAŠKE NARAVE}

Sedmi člen Haaške konvencije govori o ukrepih vojaške narave. V njegovi prvi alineji je zapisano: »Visoke pogodbenice se zavezujejo, da bodo že v mirnem času vključile v svoje vojaške pravilnike ali vojaška navodila primerne odločbe, skaterimi se zagotavlja izpolnjevanje te konvencije, in da bodo osebje svojih oboroženih sil vzgojile že v mirnem času, da spoštujejo kulturo in kulturne dobrine vseh narodov«. V drugi alineji pa je zapisano: »Zavezujejo se, da bodo že v mirnem času pripravile 
ali ustanovile v okviru svojih oboroženih sil službe ali strokovno osebje z nalogo, da bodo skrbele za spoštovanje kulturnih dobrin in sodelovale s civilnimi oblastmi, pristojnimi za zavarovanje teh dobrin« (Konvencija o varstvu kulturnih dobrin $\mathrm{v}$ primeru oboroženega spopada, 1954, str. 3).

Različne države so uporabile različne pristope pri implementaciji 7. člena Haaške konvencije. Nekatere države so ustanovile posebne vojaško-policijske oddelke. Italija je že leta 1969 ustanovila posebno enoto karabinjerjev za zaščito kulturnih dobrin, ki je med drugim sodelovala na nekaterih mirovnih misijah. V avstrijskih oboroženih silah so zaposleni (rezervni) častniki, ki so odgovorni izključno za varovanje kulturnih dobrin, $\mathrm{v}$ švicarskih oboroženih silah pa to nalogo opravljajo častniki, ki imajo posebno znanje o ohranjanju kulturnih dobrin (Senković, 2013, str. 36-37). V Slovenski vojski oziroma na Ministrstvu za obrambo trenutno ni strokovnjakov, ki bi se ukvarjali le z varovanjem kulturnih dobrin med oboroženim spopadom. Še najbolj se z njo ukvarjajo pripadniki Vojaškega muzeja Slovenske vojske. Muzej je matična muzejska ustanova Slovenske vojske, ki organizira in opravlja muzejsko dejavnost s tematiko vojaške in vojne preteklosti Slovencev ter slovenskega etničnega prostora in obrambnih sil. Temeljne dejavnosti Vojaškega muzeja Slovenske vojske so sistematično zbiranje, raziskovanje, proučevanje in strokovno obravnavanje muzejskega gradiva; izvajanje konservatorskih in restavratorskih del ter pripravljanje muzejskega gradiva za trajno shranjevanje in javno razstavljanje, objavljanje rezultatov preučevanega gradiva in njegovo uporabljanje za kulturne, znanstvene in izobraževalne namene; raziskovanje vojaških arheoloških značilnosti; ocenjevanje muzejskega vojaškozgodovinskega gradiva; opravljanje znanstvenoraziskovalnega dela ter objavljanje strokovnih in znanstvenih del ter izdajanje priložnostnih publikacij; sistematično zbiranje in hranjenje strokovne literature s področja delovanja; organiziranje muzejskih razstav in drugih oblik muzejske dejavnosti, ki imajo širši družbeni ter kulturni pomen; vodenje muzeološke evidence in dokumentacije o muzejskem gradivu ter muzejski dejavnosti v skladu s pravilnikom o vodenju inventarne knjige; posredovanje muzejskega gradiva in svojih publikacij drugim muzejem ter podobnim ustanovam v državi in tujini; spremljanje in izmenjevanje izkušenj o sodobni muzeologiji v državi in svetu; organiziranje muzejskih razstav v okviru spomeniških kompleksov velikih spopadov in bitk, zlasti v obdobju osamosvojitvene vojne leta 1991; organiziranje dejavnosti glede odpiranja muzejev rodov in služb Slovenske vojske ter spominskih sob; ukvarjanje s pedagoško-promocijskim in vzgojnoizobraževalnim delom; načrtovanje finančnih sredstev za svojo dejavnost; upravljanje materialnih in denarnih sredstev ter opravljanje materialnega in finančnega poslovanja skladno s predpisi o sredstvih in financiranju Slovenske vojske ter z določbami Pravilnika o muzejski dejavnosti v Slovenski vojski; opravljanje drugih zadev glede muzejske dejavnosti (Pravilnik o muzejski dejavnosti v Slovenski vojski, člen 9, 2005). Pripadnik Vojaškega muzeja SV je tudi civilni funkcionalni strokovnjak za področje varovanja kulturnih dobrin. Leta 2019 se je udeležil dveh mednarodnih vaj v organizaciji Večnacionalne skupine 
za CIMIC v Motti di Livenza: Double River $2019^{11}$ in Trident Jupiter 2019, kjer je bil odgovoren za področje varovanja kulturnih dobrin.

\subsection{Izobraževanje in usposabljanje oboroženih sill}

S prenašanjem skrbi za kulturne dobrine tudi na obrambni sektor so se vojaški poveljniki in drugi pripadniki oboroženih sil znašli pred nekaterimi zagatami. Zavedanje o pomenu kulturnih dobrin ni nekaj, kar bi imel vsak posameznik že ponotranjeno $\mathrm{v}$ sebi. Poleg tega imajo pripadniki različnih oboroženih sil različno znanje o varovanju kulturnih dobrin med vojaškim izobraževanjem in usposabljanjem. Raziskava, ki je bila izvedena v okviru Natovega programa Znanost za varnost in mir, žal nakazuje, da je varovanje kulturnih dobrin nekoliko zapostavljeno med usposabljanjem vojaških enot posameznih članic Nata (Rosén, 2017b, str. 21). Le dobro usposobljen pripadnik oboroženih sil bo znal ustrezno ravnati ob stiku s kulturnimi dobrinami in ne bo s svojim delovanjem pripomogel $\mathrm{k}$ njenemu poškodovanju ali uničenju. Za dobro načrtovanje in izvedbo vojaških operacij pa je danes treba tudi dobro poznati vse pravne norme in pravila glede varovanja kulturnih dobrin.

Primere dobre prakse na področju usposabljanja pripadnikov oboroženih sil za varovanje kulturnih dobrin najdemo v Združenih državah Amerike. Na podlagi izkušenj, ki so jih pripadniki oboroženih sil Združenih držav Amerike pridobili med vojaškimi operacijami, je posebna skupina strokovnjakov v vojaškem oporišču Fort Drum pripravila serijo modelov in pilotskih projektov za podporo usposabljanju pripadnikov 10. gorske divizije in Nacionalne garde. Ti modeli in projekti so med drugim zajemali pripravo replike arheološkega najdišča, na kakršno lahko pripadniki oboroženih sil naletijo na Bližnjem vzhodu, ki so ga izdelali arheologi, in je sredstvo za usposabljanje. Poleg arheološkega najdišča so bile izdelane tudi replike tradicionalnih pokopališč, saj so pripadniki oboroženih sil Združenih držav Amerike večkrat poročali, da nasprotna stran uporablja nagrobne kamne kot kritje med vojaškimi spopadi. Na vadišču Vojnega letalstva Združenih držav Amerike so bile zgrajene tudi replike starodavnih ruševin, da se lahko letalske posadke urijo v pristopu, ki bi kar najbolj zmanjšal možnost kolateralne škode med letalskimi napadi (Rush, 2017, str. 80-81, 83). Tako pripadniki oboroženih sil Združenih držav Amerike dobijo praktične izkušnje iz obnašanja na zgodovinskih območjih in ohranjanja arheoloških najdišč, še preden se odpravijo na vojaške operacije.

Pomembno vlogo pri širjenju zavedanja o pomenu varovanja kulturnih dobrin med pripadniki oboroženih sil Združenih držav Amerike ima tudi neformalno izobraževanje. Strokovnjaki iz oporišča Fort Drum so v sodelovanju z državno univerzo iz Colorada pripravili posebne igralne karte. Vsaka izmed 52 kart v paketu ima različno izobraževalno sporočilo, povezano s pomenom varovanja kulturnih dobrin. Na nekaterih kartah so fotografije pomembnih kulturnih dobrin, na drugih pa

\footnotetext{
II Več o vaji v članku z naslovom Slovenski civilni funkcionarji na vaji Double River 2019, ki je izšel v Reviji Slovenska vojska aprila 2019.
} 
navodila vojakom, kako ravnati v bližini teh dobrin. Prvi paket kart se je osredotočil na Irak in od leta 2007 je bilo razdeljenih že 150.000 paketov kart. Naslednja dva paketa kart sta osredotočena na Egipt in Afganistan (Rush, 2017, str. 87-88).

\subsection{Uporaba kulturnih dobrin in napad nanje}

S Haaško konvencijo so se visoke pogodbenice zavezale, da kulturnih dobrin in njihove najbližje okolice ne bodo uporabljale za namene, ki bi ob oboroženem spopadu lahko povzročili njihovo uničenje ali poškodovanje; da se bodo odpovedale vsakršnim sovražnim dejanjem proti takim dobrinam; da bodo prepovedale, preprečevale in, če bo treba, ustavile vsakršno obliko kraje, ropanja ali odtujevanja kulturnih dobrin, vsako vandalsko dejanje proti omenjenim dobrinam ter da ne bodo zasegale premičnih kulturnih dobrin, ki so na ozemlju druge visoke pogodbenice, in da se bodo vzdržale vseh nasilnih dejanj, namenjenih proti kulturnim dobrinam (Konvencija o varstvu kulturnih dobrin v primeru oboroženega spopada, 1954, str. 1-13). Omenjene zahteve je mogoče opustiti samo v primerih, ko to zahteva vojaška nujnost. Haaška konvencija ne pojasnjuje, kateri so ti primeri.

Kulturne dobrine se uporabljajo za vojaške namene, če se jih izkorišča za premeščanje vojaškega osebja ali materiala; če potekajo v njej dejavnosti, ki so neposredno povezane z vojnimi operacijami, če je v njej vojaško osebje ali če se v njej izdeluje vojaški material. V takih primerih lahko kulturna dobrina postane vojaški objekt (Senković, 2013, str. 22).

Veliko težavo pri obravnavani temi je pomenila nedefiniranost vojaške nujnosti v Haaški konvenciji. Šesti člen Drugega protokola k Haaški konvenciji dopolnjuje 4. člen Haaške konvencije in postavlja dva pogoja, da bi lahko uporabili izjemo vojaške nujnosti. Kulturna dobrina mora biti po svoji funkciji spremenjena v vojaški cilj, obenem pa ne smejo obstajati druge izvedljive možnosti za pridobitev podobne vojaške prednosti, kot jo daje usmeritev sovražnega dejanja zoper ta cilj (Drugi protokol k Haaški konvenciji o varstvu kulturnih dobrin v primeru oboroženega spopada, 1999). V Dopolnilnem protokolu I k Ženevskim konvencijam z dne 12. avgusta 1949 o zaščiti žrtev mednarodnih oboroženih spopadov je vojaški cilj opisan kot objekt, ki zaradi svoje narave, lokacije, namena ali uporabe pomeni efektiven prispevek k vojaški akciji in katerega delno ali popolno uničenje, zavzetje ali nevtralizacija pomeni resnično vojaško prednost (Zidar, 2019, str. 90). Šesti člen Drugega protokola ob definiciji vojaške nujnosti uvaja pomembne omejitve. Tisti, ki uporablja kulturne dobrine v namene, ki jih bodo verjetno izpostavili uničenju ali poškodovanju, se lahko sklicuje na opustitev varstva na podlagi neizogibne vojaške nujnosti samo, kadar in dokler ni na voljo nobene izbire med tako uporabo kulturnih dobrin in drugo mogočo metodo za pridobitev podobne vojaške prednosti; odločitev o sklicevanju na neizogibno vojaško nujnost lahko sprejme le častnik, ki poveljuje enoti, enaki bataljonu ali manjši enoti, če okoliščine ne dovoljujejo drugače; ob napadu je treba zagotoviti učinkovito vnaprejšnje opozorilo, kadar to dopuščajo okoliščine (Drugi protokol k Haaški konvenciji o varstvu kulturnih dobrin v primeru oboroženega spopada, člen 6, 1999). 
Leta 2003 so koalicijske sile iz zraka posnele slike, ki so dokazovale, da so iraške sile parkirale vojaška vozila med muzejski kompleks, ki je bil označen s spoznavnim znakom Haaške konvencije, in Ktezifonski obok, največji opečnati obok na svetu (Senković, 2013, str. 22). To dejanje je predstavljalo očitno kršitev Haaške konvencije. Sedmi člen Drugega protokola obravnava naključno škodo, ki doleti kulturne dobrine v spopadu. Od sil v spopadu zahteva, da pred napadom preverijo, ali cilji, ki naj bi bili napadeni, niso morda zavarovane kulturne dobrine. Sile v spopadu se morajo odpovedati napadu, za katerega je mogoče pričakovati, da bo povzročil naključno škodo na kulturnih dobrinah. Prav tako se morajo odpovedati napadu oziroma ga začasno ustaviti, če je očitno, da je cilj zavarovana kulturna dobrina in je mogoče pričakovati, da bo napad povzročil nesorazmerno naključno škodo na kulturni dobrini glede na pričakovano konkretno in neposredno vojaško prednost (Drugi protokol k Haaški konvenciji o varstvu kulturnih dobrin v primeru oboroženega spopada, člen 7, 1999). Od vojaškega poveljnika se zahteva, da opravi test sorazmernosti med morebitno vojaško prednostjo in morebitno škodo na kulturnih dobrinah. Vojaški poveljniki se lahko srečujejo s težkimi odločitvami glede varovanja kulturnih dobrin. Večkrat je težko oceniti vrednost kulturne dobrine in zato je tako pomembno usposabljanje pripadnikov oboroženih sil pred odhodom $\mathrm{v}$ vojaško operacijo ali na misijo. Med zalivsko vojno leta 1991 so iraške vojaške sile skrile dve vojaški letali med ruševine starodavnega sumerskega templja v Uru. Test sorazmernosti je prepričal koalicijsko vojaško poveljstvo, da se ni odločilo za napad. Med odločanjem so primerjali zgodovinsko vrednost templja z nevarnostjo, ki sta jo predstavljali vojaški letali. Ker v bližini ni bilo vzletne steze, sta bili letali praktično neuporabni za boj (O`Keefe in drugi, 2016, str. 35).

V Slovenski vojski je na načelni ravni poskrbljeno za varovanje kulturnih dobrin. V 321. členu Pravil službe v Slovenski vojski je med drugim zapisano, da pripadniki in enote Slovenske vojske spoštujejo kulturne, zgodovinske in naravne spomenike, verske in druge objekte, varovane po mednarodnem pravu; spoštujejo nedotakljivost objektov, ki so označeni z razpoznavnimi znaki, določenimi po mednarodnem pravu, ter jih ne napadajo; poročajo nadrejenemu o sumu kršitve mednarodnega vojnega ter humanitarnega prava (Pravila službe v Slovenski vojski, člen 321, 2009). 322. člen Pravil službe v Slovenski vojski pa prepoveduje napadati označena zaščitena območja ali objekte, kot so bolnišnice, demilitarizirana ali varna območja, nebranjene kraje ter kulturne, zgodovinske in naravne spomenike ter verske in druge objekte, zaščitene po mednarodnem pravu (Pravila službe v Slovenski vojski, člen 322, 2009). V Vojaški doktrini je zapisano, da kulturne dobrine in kulturni spomeniki ne smejo biti cilj ali se uporabljati v vojaške namene (Furlan in sod., 2006, str. 47).

Kulturna dediščina je lastnina celotnega človeštva, zato je njeno ohranjanje dolžnost celotne mednarodne skupnosti. Prve misli o njeni zaščiti so se začele pojavljati že zgodaj v človeški zgodovini, bolj poglobljeno pa so se posamezniki s tematiko začeli ukvarjati v 16. in 17. stoletju. Svoj vrh je mednarodnopravna zaščita dosegla s Konvencijo o varstvu kulturnih dobrin v primeru oboroženega spopada in njenima Prvim in Drugim protokolom. 
Sklep Kulturne dobrine imajo vedno večjo vlogo tudi pri sodobnih oboroženih spopadih. Pri tem igrajo svojo vlogo tudi oborožene sile. Pripadniki oboroženih sil morajo biti dobro usposobljeni za spoštovanje kulture in kulturnih dobrin drugih narodov ter $\mathrm{s}$ področja varovanja kulturnih dobrin, saj bodo le tako lahko primerno odreagirali ob stiku z njimi in ne bodo povzročali nenamerne škode. Prav usposabljanju s področja varovanja kulturnih dobrin bi lahko oborožene sile namenjale več pozornosti.

Varovanje kulturnih dobrin je pomembno z več vidikov. Poleg ohranjanja dediščine naših prednikov lahko skrb za kulturne dobrine pripomore k boljšemu sprejetju pripadnikov oboroženih sil od lokalnega prebivalstva, medtem ko nespoštovanje kulturnih dobrin lahko povzroči obraten proces. Skrb za kulturno dediščino je pomembna tudi za legitimacijo misije ali operacije v lokalnem področju. Preprečitev ropanja kulturnih dobrin in posledično preprečitev ilegalne trgovine kulturnih dobrin pomaga pri zmanjšanju finančnih sredstev različnih oboroženih skupin in terorističnih organizacij, kar lahko zmanjša njihovo učinkovitost in skrajša trajanje konflikta. Varovanje kulturnih dobrin pa je pomembno tudi s stališča postkonfliktne obnove. Kulturni turizem je v svetovnem merilu v porastu in tako pridobljena finančna sredstva pripomorejo k obnovi v oboroženem spopadu uničenega območja, dežele ali države.

$\mathrm{Na}$ Ministrstvu za obrambo in v Slovenski vojski je matična muzejska ustanova, ki se ukvarja z ohranjanjem kulturne dediščine, Vojaški muzej Slovenske vojske. Implementacija Haaške konvencije in njenih dveh protokolov se je na ravni obrambnega sistema v Republiki Sloveniji začela z dvema projektoma, ki ju je financiralo Ministrstvo za obrambo. V okviru projekta $\mathrm{z}$ naslovom Izdelava in demonstracija modela za načrtovanje ohranjanja umetnostnozgodovinske dediščine v vojnih spopadih je bil pripravljen seznam 70 najpomembnejših spomenikov slovenske sakralne umetnosti z izčrpno fotografsko dokumentacijo, arhitektonskimi posnetki in analizami materialov in tehnik ter s predlogi fizičnih in drugih zaščitnih ukrepov. V projektu z naslovom Varovanje kulturne dediščine v izrednih razmerah pa so bili oblikovani vzorčni primeri ter izdelane smernice za primerno varovanje kulturne dediščine v izrednih razmerah.

Omenjena projekta bi bilo treba nadaljevati na ravni celotne države ter vključiti tudi dediščino nesakralnega izvora. Vsi ti ukrepi so koristni ne le ob oboroženih spopadih, temveč tudi ob naravnih in drugih nesrečah. 
1. Drugi protokol k Haaški konvenciji o varstvu kulturnih dobrin v primeru oboroženega spopada. https://ihl-databases.icrc.org/applic/ihl/ihl.nsf/ART/590-15?OpenDocument, 7. 4. 2021.

2. Foilant, Y., 2015. Cultural Property Protection Makes Sense: A Way to Improve Your Mission. Haag: Civil-Military Cooperation Centre of Excellence.

3. Furlan, B., Rečnik, D., Vrabič, R., Maraš, V., Cerkovnik, J., Špur, B., Šonc, M., Tušak, M., Ivanuša, M., Gorjup, B., Kojadin, M., Lasič, K., Unger. M., 2006. Vojaška doktrina. Ljubljana: Poveljstvo za doktrino, razvoj, izobraževanje in usposabljanje.

4. Gottlieb, Y., 2020. Attacks Against Cultural Heritage as a Crime Against Humanity. Case Western Reserve Journal of International Law. 52-1, str. 287-330.

5. Guštin, M. (vodja projekta), 2009. Zaključno poročilo o rezultatih opravljenega raziskovalnega dela na projektu ciljnega raziskovalnega programa (CRP) »Znanje za varnost in mir 2006 - 2010«. Koper: Univerza na Primorskem, Znanstveno-raziskovalno središče.

6. Haaški pravilnik o zakonih in običajih vojne na kopnem. https://ihl-databases.icrc.org/ applic/ihl/ihl.nsf/0/1d1726425f6955aec125641e0038bfd6, 4. 8. 2021.

7. Instructions for the Government of Armies of the United states in the Field (Lieber Code). https://ihl-databases.icrc.org/applic/ihl/ihl.nsf/ART/11020035?OpenDocument, 24. 2. 2021.

8. Jogan, S., 2008. Pravno varstvo dediščine. Koper: Založba Annales.

9. Keane, D., 2004. The Failure to Protect Cultural Property in Wartime. DePaul Journal of Art, Technology \& Intellectual Property Law. 14-1, str. 1-38. https:/via.library.depaul. edu/jatip/vol14/iss1/2, 22. 2. 2021.

10. Kladnik, T., 2010. Varovanje (vojaške) kulturne dediščine in civilni nadzor. Bilten Slovenske vojske. 12-3, str. 174-191.

11. Konvencija o varstvu kulturnih dobrin v primeru oboroženega spopada. https://www. zvkds.si/sites/www.zvkds.siffiles/uploads/files/publication/konvencija_o_varstvu_kdvpos. pdf, 9. 3. 2021.

12. Murovec, B. (vodja projekta), 2009. Zaključno poročilo o rezultatih opravljenega raziskovalnega dela na projektu v okviru ciljnega raziskovalnega programa (CRP) "Znanje za varnost in mir 2006-2010«. Ljubljana: ZRC SAZU.

13. O'Keefe, R., 2006. The Protection of Cultural Property in Armed Conflict. Cambridge: Cambridge University Press.

14. O'Keefe R., Péron, C., Musayev, T., Ferrari G., 2016. Protection of Cultural Property, Military Manual. Pariz - Sanremo: UNESCO in International Insitute of Humanitarian Law.

15. Pesu, M., 2012. The Finnish National Inventory: Peacetime preparation for the protection of cultural property in the event of armed conflict. VS. Lambert, ur. in C. Rockwell, ur. Protecting Cultural Heritage in Times of Conflict. Rim: ICCROM, str. 91-96.

16. Pravila službe v Slovenski vojski. http://pisrs.si/Pis.web/pregledPredpisa?id=DRUG2422, 29. 9. 2021.

17. Pravilnik o muzejski dejavnosti v Slovenski vojski, šifra 007-7/2005-1 z dne 16. 11. 2005. Ljubljana: Ministrstvo za obrambo.

18. Rawan, Z., 2017. Great, Greatest or Outstanding: Defining Cultural Property in NATO Operational context. Nato Legal Gazette. 38, str. 100-114.

19. Register kulturne dediščine. https://www.gov.si/teme/register-kulturne-dediscine/, 30. 7. 2021.

20. Rosén, F., 2017a. Nato and Cultural Property: Embracing New Challenges in the Era of Identity Wars. København: CCHAC.

21. Rosén, F., 2017b. NATO-led military Operations and Cultural Property Protection. Nato Legal Gazette. 38, str. 19-27. 
22. Rush, L. W., 2017. The Importance of Training Cultural Property Protection: An Example from the U. S. Army. Nato Legal Gazette. 38, str. 80-91.

23. Senković, S., 2013. Mednarodna zaščita kulturnih dobrin v času oboroženih spopadov. Ljubljana: Univerza v Ljubljani, Pravna fakulteta.

24. Severnoatlantska pogodba. https://nato.gov.si/slo/dokumenti/severnotatlantska-pogodba/, 30. 7. 2021.

25. Sveto pismo Stare in Nove zaveze, 2016. Ljubljana: Svetopisemska družba Slovenije.

26. Turku, H., 2018. The Destruction of Cultural Property as a Weapon of War, ISIS in Syria and Iraq. London: Palgrave Macmillan.

27. Zakon o varstvu kulturne dediščine. http://pisrs.si/ Pis.web/ pregledPredpisa?id=ZAKO4144, 4. 8. 2021.

28. Zidar, A., gl. ur., 2019. Ženevske konvencije in Dopolnilni protokoli, II. del-Protokoli. Ljubljana: MZZ RS in Založba FDV. 